\title{
IMPLEMENTATION OF CLIL AT THE UNIVERSITY LEVEL: THE CASE OF LOGISTICS COURSE
}

\begin{abstract}
The purpose of this article is to show the necessity to implement bilingual teaching at university education. At the present time, as we are witnessing the globalization process, university students need to master the second language skills, especially English, in order to become competitive in a labour market. Nonetheless, the demand of modern times development requires from students to use professional language, strictly connected with the major of their study. English language has become an add-on to any university curricular program, yet it came to be a tool to learn something else. It is Content and Language Integrated Learning (CLIL), a methodology introduced by David Marsh, that views language as a vehicle to learn through English. CLIL is a response to the global changes, to be innovative, creative and dynamic. This innovation is entitled in methods and approaches as CLIL entails teaching the foreign language while students learn the subject-matter. In the given paper, the benefits of the implementation of the bilingual programs are discussed as well as difficulties in assimilating academic content through the language process. Yet, this paper on CLIL aims at analyzing the way Polish university lecturers and academics might structure their lectures as well as classes and take advantage of this approach, i.e. incorporating English as a medium of instructions, chiefly in postgraduate programs.
\end{abstract}

Keywords: Content and Language Integrated Learning (CLIL), English, Higher Education.

\section{INTRODUCTION}

David Marsh in his seminal paper entitled "Content and Language Integrated Learning: The European Dimension - Actions, Trends and Foresight Potential explains that content and language integrated learning (CLIL) refers to any dual-focused educational context in which an additional language, thus not usually the first language of the learners involved, is used as a medium in the teaching and learning of non-language content", . The author points out that the process is dual-focused since while attention may be mainly on either subject-specific content or language, both are always accommodated and billeted. Dulton-Puffer and Wolff argue that this approach is presently implemented in differing ways depending on the age-range and location of learners, especially in primary schools throughout Europe ${ }^{4}$. Interestingly, it is most commonly realized by

\footnotetext{
${ }^{1}$ Anna Dziama, PhD, Assistant Professor - The University of Rzeszów, Institute of English Studies, Al. mjr. W. Kopisto 2 B, 35-315 Rzeszów.

${ }^{2}$ Magdalena Rejman-Zientek, MA - The Rzeszow University of Technology, The Faculty of Management, Department of Quantitative Methods, al. Powstańców Warszawy 10, PL - 35959 Rzeszów, corresponding author: mzientek@prz.edu.pl

${ }^{3}$ D. Marsh, Content and Language Integrated Learning: The European Dimension - Actions, Trends and Foresight Potential. (retrieved from http://userpage.fuberlin.de/elc/bulletin/9/en/marsh.html), 2002, p. 34.

${ }^{4}$ Ch. Dalton-Puffer., Discourse in CLIL classrooms, Amsterdam et al.: Benjamins, 2007, p.67.
} 
teachers of foreign languages and those of other subjects i.e. Mathematics, Science, Music, who might, for example, offer so called language showers for 6-10 year olds, which involves 30 minutes to one hour language exposure per day; then, language encounters for 10-14 year olds, which comprises experiential blocks of some, so to say, 40 hours before or equivalent to formal language instruction. What is more, so called dual-focused learning for 14-19 year olds, interestingly, in academic streams, which is, at least, 5-10 hours per week, and at that point, competence building for 16-19 year olds in vocational education and training. However, one particular group to be focused are 19 and older university students to be focused on and exposed to CLIL. As examined by Marsh "there are many variants now active in European mainstream education differing not only in terms of implementation but also goals" $"$. There is a growing amount of evidence that one very important factor affecting students foreign language acquisition is selfconfidence and language awareness. If we look at CLIL model, these range from preparing children at pre-school or primary school for language learning through language awareness activities, to building self-confidence through skills development for certain vocational sector students, either the construction or logistics, who, as we assume, might not have reacted favorably to earlier language instructions and teachings.

One has to mention, as observed by Marsh that over the last five decades finest practice in teaching and learning foreign languages has progressed from emphasis on grammar and translation in the 1950s, behaviorist forms of rote learning in the 1960s and the communicative approach of the 1970s, to those which stress form and function in the present day. Marsh summarizes that by stating: "put simply, knowledge of a language has given way to pragmatic competence whereby a person has both knowledge and skills for actively using the given language" .

Interestingly, in the 1950s it was often only particular students who took on additional language learning, by the end of the century such establishment was extended to general school populations. Therefore, more students were seen to prerequisite more language ability, and to realize this additional motivation was assumed by numerous educational specialists, academics and teachers in a variety of countries as to how and when languages are best taught and learned. It was not long ago, in the 1990s that the European Commission made a recommendation that all school leavers should have particular and certain competence in both the mother tongue and two European community languages. This policy facilitated to form best educational goals, then the question of recognizing an suitable 'platform for delivery' has continued to be chiefly unsolved. As Marsh explains "the reason for this has generally not been due to lack of knowledge of what could be done, but rather the inability to visualize how it could be achieved"'

Marsh and Wolff believe that language teaching and learning, as conveyed through the widely differing educational systems of the European Union member states, undoubtedly requires assessment, further development and review in one form or another ${ }^{8}$. Thus, they argue that contemporary languages education has regularly failed to offer stages and platforms for learning which ensemble a wide-ranging group of people,

\footnotetext{
${ }^{5}$ D. Marsh, op. cit. , p.34.

${ }^{6}$ Ibidem, p.42.

${ }^{7}$ Ibidem, p.42.

${ }^{8}$ D. Marsh, D. Wolff (eds.)., Diverse Contexts - Converging Goals. CLIL in Europe, 2007, pp.1525 .
} 
those younger and some older. Accordingly, it is CLIL has occurred as a pragmatic European solution to a European need. It has been often pointed out that CLIL has been suggested in conjunction with assertions that foreign languages are not adequately taught or learned in schools and that a substantial investment in this field is needed for, namely, a cost-effective, practical and sustainable solution might be set up in this new, though teacher -challenging approach.

Given the added value of the approach, it is viewed according to different sectors and types. First and foremost, as explained by Marsh "this is in terms of providing greater individual economic opportunities and benefits, which, in turn, provides greater overall economic return on investment in language education"9. What is more, one has to mention that there is likelihood to enhance such skills and abilities as social inclusion, egalitarianism, social equality by providing and enabling a larger array of young people with alternative and unconventional platforms for learning foreign languages which is proper for the specific styles and individual personalities, predominantly with respect to learning strategies, as enumerated by Marsh i.e.:

"gender mainstreaming in terms of male and female performance in language learning; reaping the benefits of naturalistic early language learning; the relevance and value of limited and domain-specific competencies in languages; opportunities for learners to be linguistically prepared to take up their rights to study in other countries; school development which may lead to improvement of educational environments" ${ }^{\prime 10}$.

Accordingly, it has been highlighted by Marsh and Wolff that "the impact of national and European initiatives, alongside professional developments within language teaching, and, in particular, grassroots demands, have resulted in its emergence as an educational innovation which suits the times, needs and aspirations of learners" ${ }^{11}$. Moreover, in terms of foreign language learning there are numerous indications that so-called older learners, in our case university students, are increasingly reluctant to learn now for use later, but prefer to learn as you use and use as you learn, which is appropriate for the the juxtaposition of determination and purpose mutual to the times and university vocational courses. Therefore, the issue of mobility and the forthcoming broadband roll out are correspondingly well-thought-out to added impact on learner attitudes and outlooks towards how university students learn, above all, with regard to foreign language teaching.

\section{DESIGNING BILINGUAL PROGRAMS FOR HIGHER EDUCATION}

In the course of the globalization process university students, in order to be competitive in a labor market, need to master the second language, especially English, which is some kind of an added value. However, everyday language is not sufficient today, students need to learn the professional language, strictly connected with the major of study. This is the language of instructions, teaching and research materials, during students exchanges and graduate employability. Some universities provide bilingual education policy and design programs and curricula which take into account the characteristics of the subject. However, one needs to be aware that the implementation of the programs requires some conditions which should be met. This is not only the change

\footnotetext{
${ }^{9}$ D. Marsh, op. cit., 39-45.

${ }^{10}$ Ibidem, p. 39-45.

${ }^{11}$ D. Marsh, D. Wolff (eds.)., op. cit., p. 44.
} 
of the language in which the subject is taught. Students need to possess a high command of the second language but also teachers need to be fluent. There are many benefits of the implementation of the bilingual programs at universities. They concern both the benefits for the universities as well as for the students. As for the university, first of all, its attractiveness enhances; more national and international students are attracted. There is a possibility of collaboration with other universities, with industry and other professional institutions. The development of educational and economic partnership with other countries is also possible. Among others there are also cognitive benefits (creativity, paying more attention to the language forms and uses). As for the benefits for students one can mention, inter alia, about: the opening of new opportunities for students in the labor market. Students master subject-specific literacies in English, they get accustomed to the terminology in English. The understanding of new terms in English leads to a deeper engagement with these terms, through, e.g. searching for materials in the Internet. Students develop new information sheet with data collected from English sources; they also develop translation skills from English into Polish.

\section{DIFFICULTIES IN ASSIMILATING ACADEMIC CONTENT THROUGH LANGUAGE}

While implementing the bilingual program some initial problems may occur. First of all students may encounter some difficulties in assimilating academic content through a language. Secondly, the academic content may not be acquired at the same level as it was taught in the native language. However, Hellekjaer and Wilkinson report that recent studies have revealed that students engaged in academic teaching programs using an additional language skill achieve the same or even better academic performance than their peers who study in programs taught in their mother tongue ${ }^{12}$. That is why it is important to establish an initial level of language competence for the students. The language should not be an obstacle which will have a negative influence on their academic performance. Therefore, it should be introduced in a gradual and sensible way. But not only do the students encounter the problem, it is also related to the language proficiency of their teacher. Thus, it is not only the matter of a command of the foreign language, but it is the matter of explanation, classification, responding to questions. It is the matter of a general language proficiency and competence in different linguistic skills. Therefore, the establishment of a minimal level of language competence is essential.

\section{STRATEGIES APPLIED WHILE TEACHING SPECIFIC UNIVERSITY} COURSES

Teaching specific university courses in English is a long-term process which requires a continuous improvement and an application of many strategies. From the very beginning of the course students should be aware of the importance of studying the subject in a foreign language. Students should achieve the goals of the subject and, at the same time, they should improve English proficiency. By using various language strategies students expand their knowledge and improve their comprehension. One of the strategy is an acquisition of professional vocabulary in English. For many students this is the first

\footnotetext{
${ }^{12}$ G.O. Hellekjaer, R. Wilkinson, CLIL in higher education, EuroCLIL, Bulletin 7. (retrieved 2 April 2012 from the net: http://www.euroclil.net/index.php?inhound=inhound/ulletins/bulletin7/8.htm), 2009, p. 9.
} 
exposure to this type of vocabulary. It is the role of the teacher to constantly use these words and students need to repeat them and use in the context. When students hear these examples, they realize the importance of studying the subject in a foreign language. Fiorito notes:

"As a matter of fact English for Specific Purposes combines subject matter and English language teaching. Such a combination is highly motivating because students are bale to apply what they learn in their classes to their main field of study, whether it be accounting, business management, economics, computer science or tourism. Being able to use the vocabulary and structures that they learn in a meaning context reinforces what is taught and increases their motivation"13.

Therefore, acquiring the professional vocabulary is one of the most important goals of this and any other content-based course. Charles Van Leeuwen adds a similar conclusion:

"If the university intends to provide its students with a well-considered language teaching program that enables them to reach a substantial level, this will involve many hours of study, many credits and high costs. A student who takes the language as a subsidiary subject may be slightly hesitant to make such an investment and the necessary funds are often is short supply at modern universities! It makes it clear why language learning through content learning presents a welcome solution; content becomes an instrument for language learning and language learning is instrumental for the content" ${ }^{\text {"14 }}$.

Thanks to this strategy students are well-motivated, they improve English proficiency, they are aware of the importance of studying the subject in a foreign language. But it needs to be, so called, live English, that is why it is necessary to find authentic sources such as books, journal or websites. This is a role of the teacher to select a topic-related reading and then adjust it accordingly to the language level as well as to the goals which need to be accomplished. There are some solutions to make it easier. Teachers may shorten the text, remove unnecessary information, divide long paragraphs into shorter pieces. They may use extra, multimodal input (supplement the text with examples visuals, charts or graphs, may give some examples to clarify complex concepts. Some pre-reading tasks pictures, words translation, questions) may be provided. However, students also need to speak in a foreign language, how to break the language barrier Kurtan says: It is necessary to introduce various interactional strategies in teaching to foster a more interactive climate characterized by greater student participation ${ }^{15}$. The teacher may encourage students by showing a couple of examples, be resolving problems, by providing feedback and by workgroup. Students must play active roles in class. The constant interaction between the teacher and the students is necessary. Fiorito advises:

"The students are handicapped because they are unable to use their native language competence to present themselves as well-informed adults. That is why the teacher should create an atmosphere in the language classroom which supports the students. Learners

\footnotetext{
${ }^{13}$ L. Fiorito, Teaching English for specific purposes (retrieved from http://www.usingenglish.com/articles/teaching-english-special-puroses.html), 2005, p.23.

${ }^{14}$ C. Van Leeuwen, Feasibility of policy in university language teaching today. In Multilingual approaches in university education. Challenges and practices. Maastricht University. The Netherlands, 2003, pp.67-76.

15 Z. Kurtan, Teacher training for English-medium. University of Veszprem, Hungary. In Multilingual approaches in university education, challenges and practices. Maastricht University. The Netherlands, 2003, p. 57.
} 
must be self-confident in order to communicate and you have the responsibility to help build the learner's confidence" 16 .

Teachers, themselves, must be interested in the topic, they should have the goodwill to develop lessons and should have an access to various sources. But how to check student's comprehension of such kinds. One of the ways and methods is to do it by writing exercises as "writing effectively demands adequate knowledge of the rhetoric and specific content area" ${ }^{17}$. However, the teacher needs to present some kind of background to make the task easier and to motivate students as some part of the given form and the source materials might be too difficult for students to understand and comprehend. Owing to this approach, students might improve their language proficiency, learn the topic, gain confidence, hence the future employability.

\section{BILINGUAL LANGUAGE IMPLEMENTATION INTO THE COURSE}

\section{OF LOGISTICS}

According to the definition by Longman Dictionary of Applied Linguistics, bilingual teaching is: the use of a second or foreign language in school for the teaching of content subjects. In simple words this is a teaching of professional course in a foreign language. The course of Logistics is closely related to English within such areas as shipping, making orders, filling in documents, the implementation of the foreign language is a must. In the process of teaching the course at university, the teacher should focus on diversified teaching means with the use of foreign original logistics textbooks. Thanks to this students master the content and at the same time the ability to use English. Together with the development of logistics industry, there is a high demand for specialists with interdisciplinary skills. This is the role of the lecture to teach the basic theories on logistics, at the same time paying attention to improve students' abilities of English comprehensive skills. For this purpose teacher should check the level of English and adjust it to the student. In bilingual teaching the use of two languages is not even; it depends on the student's language skills, but also on the teaching objective. It should be done in the process of designing the university curriculum in Logistics. The curriculum needs to refer to original logistics textbooks, as well as the Internet sources. While teaching the subject various methods should be applied. One of the suggestion is a student-centered interactive teaching method, such as for example role-playing. Students need to express their opinions on various logistics issues. A case study is also a good method, which enables the students to solve various problems. Role-playing method, e.g. on international logistics allows students to play roles of a forwarding agent or a shipper; thanks to it student's creativity can be inspired. However, during the course implementation some problems may occur.

If the teacher has no sufficient professional knowledge or he foreign language is of low level, it may affect the quality of teaching and as a result students may lose their interest. So the university should put more emphasis on training the teachers. Students also need to meet the needs of foreign language, but also they should have some preliminary knowledge on the subject. That is why more attention should be put on

\footnotetext{
${ }^{16}$ L. Fiorito, op. cit., p.23.

${ }^{17}$ R. Wilkinson, G.O. Hellekjaer, Trends in content learning through English at universities: A critical reflection. In Multilingual approaches in university education. Challenges and practices. Maastricht University. The Netherlands, 2003, p. 9.
} 
improving students reading, listening or speaking abilities and change English teaching for examination to for application. Also, the foreign language should be introduced gradually. At the beginning students should get familiar with professional terminology, they need to encouraged to see professional dictionary. The content teaching at first should become more complex. At that stage the proportion of the foreign language vs. mother tongue should be changed. During the course bilingual textbooks should be used. However, they are still not available, mostly due to the price. One of the solutions is to edit applicable bilingual textbooks which would consider and combine with national conditions.

\section{CONCLUSIONS}

In conclusion, when using CLIL, both language and content are simultaneously paid attention to, and they are both relevant in the learning process. The language is used as a tool to learn the contents of the subject and the contents are used to learn and use the language communicatively. While implementing CLIL in the educational process the following aspects should be considered, for instance adequate target-language competence, subject knowledge, teacher training, teacher cooperation. Students develop literacy in two languages and can look beyond the English-speaking world for employment. Dalton-Puffer and Smit argue that to learn a language and subject simultaneously provides an extra means of educational delivery which offers a range of benefits relating to both learning of the language, and also learning of the non-language subject matter ${ }^{18}$. It is worth pointing out that, in addition to the approach explained above, there are social, community, psychological, commercial and economic benefits and profits that suit administrative and political policies and goals of each and given EU member state. Thus, there is a need to consider CLIL in terms of language policy, planning, and politics at a Higher education level, to be more precise, University or Technical University stages.

\section{REFERENCES}

[1] Dalton-Puffer, Ch., Discourse in CLIL classrooms. Amsterdam et al.: Benjamins 2007.

[2] Dalton-Puffer, Ch.; Smit, U. (eds.), Empirical perspectives on CLIL classroom discourse. Frankfurt a. M.: Lang 2007.

[3] Deller, S. and Price C., Teaching Other Subjects through English. Oxford. Oxford University Press 2007.

[4] Chun, F., Research on Implementing Bilingual Teaching of Logistics Engineering laboratory course, Journal of Peking University (Philosophy and Social Science Edition), no.2., 2007.

[5] Fiorito, L., Teaching English for specific purposes 2005 (retrieved from http://www.usingenglish.com/articles/teaching-english-special-puroses.html)

\footnotetext{
${ }^{18}$ Ch. Dalton-Puffer, U. Smit, (eds.)., Empirical perspectives on CLIL classroom discourse. Frankfurt a. M.: Lang., 2007, p.76
} 
[6] Hellekjaer, G.O. and Wilkinson, R., CLIL in higher education 2009.. EuroCLIL, Bulletin 7.(retrieved 2 April 2012 from the net: http://www.euroclil.net/index.php?inhound=inhound/ulletins/bulletin7/8.htm).

[7] Kurtan, Z., Teacher training for English-medium. University of Veszprem, Hungary. In Multilingual approaches in university education, challenges and practices. Maastricht University. The Netherlands 2003.

[8] Marsh, D.; Wolff D. (eds.)., Diverse Contexts - Converging Goals. CLIL in Europe 2007.

[9] Mehisto, P., Frigols, M-J, Marsh D., Uncovering CLIL. London: Macmillan 2008

[10] Van Leeuwen, C., Feasibility of policy in university language teaching today. In Multilingual approaches in university education. Challenges and practices. Maastricht University. The Netherlands 2003.

[11] Wilkinson, R. and Hellekjaer, G.O., Trends in content learning through English at universities: A critical reflection. In Multilingual approaches in university education. Challenges and practices. Maastricht University. The Netherlands 2003.

\section{WPROWADZENIE KSZTAŁCENIA JEZYKOWO-PRZEDMIOTOWEGO W UCZELNIACH WYŻSZYCH NA PRZYKŁADZIE KURSU Z LOGISTYKI}

Język obcy jest dzisiaj narzędziem pracy i nauki pozwalającym na swobodne funkcjonowanie w świecie otwartych horyzontów i bezustannego rozwoju. Badania naukowe potwierdzają, iż dla młodych ludzi nauczanie dwujęzyczne jest bardzo atrakcyjne. W dobie globalizacji studenci, aby stać się konkurencyjni na rynku pracy, muszą opanować umiejętności językowe drugiego języka, zwłaszcza języka angielskiego. Jednakże, współcześnie wymagana jest znajomość języka zawodowego, ściśle związanego z kierunkiem studiów. Odpowiedzią na globalne zmiany jest właśnie CLIL (Content and Language Integrated Learning), czyli zintegrowane kształcenie językowo-przedmiotowe, metoda wprowadzona przez Davida Marshala. Głównym założeniem tej metody jest zdobywanie nowej wiedzy i jednoczesne obcowanie $\mathrm{z}$ językiem obcym, uczenie się $\mathrm{i}$ używanie go. Wartością dodaną tej metody jest zapewnienie słuchaczom możliwości opanowania języka angielskiego na wysokim poziomie $\mathrm{z}$ bogatym słownictwem specjalistycznym z różnych dziedzin wiedzy. CLIL prócz języka i treści międzyprzedmiotowych uczy samodzielności, kreatywności, analizy, czy syntezy. Celem niniejszego artykułu jest pokazanie konieczności wdrożenia kształcenia dwujęzycznego w edukacji uniwersyteckiej. W artykule przedstawiono korzyści wdrażania programów dwujęzycznych a także trudności $\mathrm{w}$ przyswajaniu treści nauczania $\mathrm{w}$ procesie edukacji językowej. Pokazano również, w jaki sposób wykładowcy uniwersyteccy i naukowcy mogą organizować swoje wykłady, a także zajęcia i skorzystać z tego podejścia.

Słowa kluczowe: Zintegrowane kształcenie językowo-przedmiotowe (typu CLIL), język angielski, kształcenie uniwersyteckie

DOI:10.7862/rz.2014.hss.15

Przesłano do redakcji: marzec 2014

Przyjęto do druku: lipiec 2014 